\title{
Penerapan Model Pembelajaran Kooperatif Tipe Think-Pair- Share (TPS) untuk Meningkatkan Aktivitas dan Prestasi Belajar Matematika
}

\author{
*Kamelia Olga Litna1, Maria S. Seli² \\ 1 Program Studi Penelitian dan Evaluasi Pendidikan Universitas Pendidikan Ganesha Singaraja, Indonesia \\ ${ }^{2} S D K$ Warat, Kabupaten Manggarai Timur-NTT, Indonesia
}

\section{A R T I C L E I N F O}

Article history:

Received 15 August 2019

Received in revised form

20 September 2019

Accepted 10 October 2019

Available online 30

November 2019

Kata Kunci:

think-pair-share, aktivitas

belajar.

Keywords:

think-pair-share, learning activities.

\begin{abstract}
A B S T R A K
Pencapaian prestasi belajar matematika di sekolah cenderung lebih rendah dibandingkan dengan bidang studi lainnya. Hal ini disebabkan dalam kegiatan pembelajaran matematika guru cenderung tidak menggunakan model pembelajaran yang inovatif. Pemilihan model pembelajaran yang bersifat satu arah atau yang berpusat pada guru menjadi salah satu penyebab rendahnya aktivitas dan prestasi belajar matematika siswa. Aktivitas belajar merupakan prinsip yang penting dalam interaksi belajar mengajar. Aktivitas belajar berpengaruh secara langsung terhadap prestasi belajar yang diperoleh. Aktivitas belajar yang baik akan mampu menghasilkan prestasi belajar yang tinggi. Penelitian ini bertujuan untuk meningkatkan aktivitas dan prestasi belajar matematika siswa melalui penerapan model pembelajaran kooperatif tipe TPS. Jenis penelitian ini adalah penelitian tindakan kelas yang terdiri dari dua siklus. Data dalam penelitian ini diperoleh melalui wawancara, observasi dan tes. Subjek penelitian adalah kelas IV SD yang berjumlah 20 siswa. Berdasarkan analisis data yang telah dilakukan diperoleh rata-rata aktivitas belajar siswa pada siklus I adalah 37,67 kategori cukup aktif, kemudian meningkat pada siklus II menjadi
\end{abstract} 53,83 dengan kategori aktif. Hasil prestasi belajar siswa pada siklus I adalah 62,65 meningkat menjadi 76,2 pada siklus II. Dengan demikian, hasil penelitian ini menunjukan bahwa penerapan model pembelajaran kooperatif tipe think-pair-share (TPS) dapat meningkatkan aktivitas dan prestasi belajar matematika siswa.

\section{A B S T R A C T}

The aim of this research is to improve the students' mathematics learning activity and mathematical achievement of students, through the application of cooperative learning TPS type. The type of the research is a classroom action research contain the two cycles. The data obtained through interviews, observations and tests. The subjects of research is class IV A of SDK Warat. Based on analysis data, the results of student learning activity in cycle I showed 37,67 with category "fairly active" and then increased in cycle II to 53,83 active categories. The results of student achievement in cycle I was 62,65 increased to 76,2 in cycle II. Thus, the results of this study indicate that the application of cooperative learning think-pair-share (TPS) can improve students' mathematics learning activities and achievement.

\section{Pendahuluan}

Pendidikan merupakan sarana yang diperlukan dalam mengembangkan sumber daya manusia. Pendidikan memiliki peran yang besar dalam mengarahkan dan mengembangkan potensi yang dimiliki manusia. (Notoatmodjo, 2003) mengatakan pendidikan adalah segala upaya yang direncanakan untuk mempengaruhi orang lain baik individu, kelompok, atau masyarakat sehingga mereka melakukan apa yang diharapkan oleh pelaku pendidikan. Pendidikan yang berkualitas menghasilkan manusia yang berkualitas yang mampu bersaing di era global. Oleh karena itu pendidikan harus diarahkan dengan baik agar mampu menghasilkan kualitas sumber daya manusia yang baik. 
Salah satu bidang pendidikan yang dipelajari oleh siswa adalah matematika. Matematika adalah ilmu yang membahas pola atau keteraturan (pattern) dan tingkatan (order). Matematika adalah pengetahuan atau ilmu mengenai logika dan problem-problem numerik dan matematika membahas faktafakta dan hubungan-hubungan serta membahas problem ruang dan waktu (Fathani, 2009). Senada dengan hal tersebut, Erman Suherman dalam Triyani (2009: 8) menyatakan bahwa matematika sebagai salah satu ilmu dasar yang terus berkembang, baik materi maupun kegunaannya. Matematika pada dasarnya memegang peran yang penting dalam berbagai disiplin ilmu serta dapat dimanfaatkan dalam memecahkan berbagai masalah dalam kehidupan sehari-hari. Melalui pembelajaran matematika, diharapkan mampu meningkatkan daya pikir siswa dan dijadikan landasan untuk bernalar. Disisi lain pembelajaran matematika menjadi salah satu pelajaran yang seringkali dianggap paling susah oleh siswa. Hal tersebut dikarenakan kurangnya variasi dalam kegiatan pembelajaran matematika, sehingga menyebabkan rendahnya aktivitas dan prestasi belajar matematika siswa.

Aktivitas belajar merupakan prinsip yang penting dalam interaksi belajar mengajar. Aktivitas belajar berpengaruh secara langsung terhadap prestasi belajar yang diperoleh. Aktivitas belajar yang baik akan mampu menghasilkan prestasi belajar yang tinggi. Prestasi belajar adalah hasil yang telah dicapai dari proses usaha yang dilakukan seseorang untuk memperoleh perubahan tingkah laku atau perilaku sebagai hasil dari pengalaman (Teresia Olivia Oennus, Erni, 2019). (Muhibbin Syah, 2008) Mengemukakan bahwa prestasi belajar merupakan hasil dari sebagian faktor yang mempengaruhi proses belajar secara keseluruhan. Pencapaian prestasi belajar matematika di sekolah cenderung lebih rendah dibandingkan dengan bidang studi lainnya. Hal ini disebabkan dalam kegiatan pembelajaran matematika guru cenderung tidak menggunakan model pembelajaran yang inovatif.

Pemilihan model pembelajaran yang bersifat satu arah atau yang berpusat pada guru menjadi salah satu penyebab rendahnya aktivitas dan prestasi belajar matematika siswa. Menurut informasi yang diperoleh dari guru matematika diketahui bahwa aktivitas dan prestasi belajar siswa dalam pembelajaran matematika belum mancapai kategori yang telah ditetapkan. Perolehan nilai rata-rata hasil belajar matematika di kelas IV A SDK Warat masih dibawah kriteria ketuntasan minimal (KKM) yang ditetapkan di sekolah tersebut yaitu nilai rata-rata prestasi belajar yang diperoleh siswa adalah 39,5, daya serap 39,5 $\%$ dan ketuntasan belajar mencapai $20 \%$.

Dari hasil observasi yang dilakukan terlihat bahwa proses belajar mengajar di kelas masih menggunakan metode ceramah sehingga antusiasme siswa dalam mengikuti pembelajaran sangat rendah. Selain itu interaksi antar siswa masih kurang, belum adanya pembentukan kelompok dalam pembelajaran, proses belajar mengajar banyak didominasi oleh siswa-siswa yang berkemampuan tinggi, dan siswa tidak berpartisipasi dalam menyimpulkan materi pelajaran. Oleh karena itu untuk mengatasi masalah tersebut perlu diterapkannya model pembelajaran yang aktif yang mampu meningkatkan aktivitas dan prestasi belajar siswa.

(Muthoharoh, 2017) Model pembelajaran adalah suatu pola yang berbentuk pola konseptual yang disusun secara terstruktur yang digunakan sebagai pedoman oleh guru dalam menyampaikan pembelajaran di kelas, dimaksudkan model pembelajaran dapat membuat pembelajaran di kelas menjadi kooperatif dan dapat meningkatkan hasil belajar peserta didik. Model pembelajaran kooperatif adalah model pembelajaran yang melibatkan partisipasi siswa dalam suatu kelompok kecil untuk saling berinteraksi (Majid, 2014). Selanjutnya, (Sanjaya, 2010) pembelajaran kooperatif merupakan model pembelajaran dengan menggunakan sistem pengelompokan/tim kecil, yaitu antara empat sampai enam orang yang mempunyai latar belakang kemampuan akademik, jenis kelamin, ras, atau suku yang berbeda (heterogen). Pembelajaran kooperatif (cooperative learning) dilakukan dengan cara siswa belajar dan bekerja dalam kelompok-kelompok kecil secara kolaboratif, yang anggotannya terdiri dari 4 sampai dengan 6 orang, dengan struktur kelompok yang bersifat heterogen.

Think Pair Share (TPS) merupakan salah satu tipe pembelajaran kooperatif yang mampu meningkatkan aktivitas dan prestasi belajar siswa. Pembelajaraan kooperatif tipe TPS pertama kali dikembangkan oleh Frank Lyman, menyatakan bahwa Think-Pair-Share merupakan suatu cara yang efektif untuk membuat variasi pola diskusi kelas (Trianto, 2009). Pembelajaraan kooperatif tipe TPS memiliki prosedur yang ditetapkan secara eksplisit untuk memberi siswa lebih banyak untuk berfikir, menjawab dan saling membantu satu sama lain. (Joyce B., Weil M., 2009) Latihan bekerja sama bisa dilakukan dengan pengelompokan sederhana, yakni dengan dua siswa dalam satu kelompok yang ditugaskan untuk menyelesaikan tugas kognitif. Kothiyal, dkk (2013: 137) mengatakan bahwa TPS is a classroom-based active learning technique, in which students work on a problem posed by the teacher or instructor. Artinya TPS merupakan teknik pembelajaran aktif berbasis kelas, dimana siswa menyelesaikan masalah yang diajukan oleh guru. (Kurniasih, 2017) model pembelajaran Think-Pair Share (TPS) atau berpikir berpasangan berbagi adalah jenis pembelajaran kooperatif yang dirancang untuk mempengaruhi pola interaksi siswa. jadi, dapat disimpulkan bahwa model pembelajaran kooperatif tipe TPS merupakan 
salah satu model pembelajaran yang mampu memberikan kesempatan kepada siswa untuk mengemukakan jawaban yang sangat tepat, serta mendorong siswa untuk meningkatkan kerja sama antar siswa. (Hardyanti Arki et al., 2017) Dalam metode kooperatif tipe TPS ini, pembelajaran dilakukan dengan terlebih dahulu memberikan masalah kepada siswa yang harus dipecahkan secara individual (Think) kemudian guru membagi siswa secara berpasangan dalam kelompok sebanyak 4 orang (2 Pair). Dalam kelompok tersebut, setiap siswa membagi hasil buah pikirnya ke setiap anggota kelompoknya (Share). (Handayani \& Yanti, 2017)Think Pair Share merupakan model pembelajaran yang memberi kesempatan kepada peserta didik untuk berpikir terlebih dahulu sebelum didiskusikan dengan pasangannya dan dipersentasikan didepan kelas, belajar sendiri dan bekerja sama dengan orang lain. (Leonard, Leonard, 2015) Pembelajaran Kooperatif model Think-Pair-Share ini relatif lebih sederhana karena tidak menyita waktu yang lama untuk mangatur tempat duduk ataupun mengelompokkan siswa. Pembelajaran ini melatih siswa untuk berani berpendapat dan menghargai pendapat teman". Dengan demikian peserta didik memiliki kesempatan waktu yang lebih banyak untuk berpikir dalam memecahkan suatu masalah dan melakukan kerja sama dengan teman sebaya atau membagikan pengetahuan yang dimilikinya dalam bentuk diskusi kelompok kecil, sehingga peserta didik terlihat aktif dalam pembelajaran

Adapun langkah-langkah penerapan strategi Think-Pair Share (TPS) adalah sebagai berikut: (1) Thinking (berpikir). Guru mengajukan suatu pertanyaan atau masalah yang dikaitkan dengan pelajaran, dan meminta siswa menggunakan waktu beberapa menit untuk berpikir sendiri jawaban atau masalah. (2) Pairing (berpasangan). Guru meminta siswa untuk berpasangan dan mendiskusikan apa yang telah mereka peroleh. Interaksi pada tahap ini diharapkan dapat berbagi jawaban atau ide. Guru memberi waktu tidak lebih dari 4 atau 5 menit untuk berpasangan. (3) Sharing (berbagi). Guru meminta pasanganpasangan untuk berbagi dengan dengan siswa lain yang telah mereka bicarakan.

\section{Metode}

Pendekatan yang digunakan dalam penelitian ini adalah pendekatan kualitatif. Moleong (2012:8) menyatakan penelitian kualitatif adalah penelitian yang dilakukan pada latar alami atau pada konteks dari suatu keutuhan (entity) dengan memanfaatkan diri peneliti sebagai instrument kunci. Jenis penelitian ini yang akan dilaksanakan adalah penelitian tindakan kelas (Classroom Action Research) adalah suatu kegiatan peneliti untuk mengamati sebuah kegiatan pembelajaran yang diberikan tindakan dalam sebuah kelas yang bertujuan memecahkan masalah atau meningkatkan mutu pembelajaran di kelas tersebut (Trianto, 2011). Desain penelitian yang digunakan dalam penelitian ini adalah desain Kemmis dan McTaggart, yang terdiri dari 4 tahap, yaitu: perencanaan, pelaksanaan tindakan dan observasi, serta refleksi seperti gambar 1 berikut.

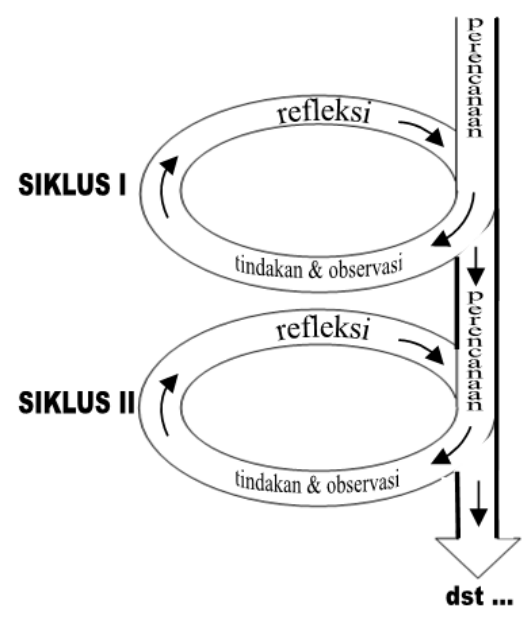

Gambar 1.

Desain PTK Model Kemmis dan McTaggart

(Diadopsi dari (Susilo, 2008))

Penelitian dilaksanakan di SDK Warat yang berlokasi di Kabupaten Manggarai Timur, Provinsi Nusa Tenggara Timur. Subjek penelitian ini adalah siswa kelas IVA SDK Warat pada semester I tahun pelajaran 2019/2020 yang berjumlah 20 siswa. 
Data yang dikumpulkan dalam penelitian ini meliputi data aktivitas belajar siswa, data prestasi belajar siswa, data keterlaksanaan pembelajaran dan catatan lapangan. Data aktivitas belajar siswa dikumpulkan dengan metode observasi berupa instrumen lembar observasi aktivitas belajar siswa. Data prestasi belajar siswa dikumpulkan dengan metode tes. Tes yang diberikan berupa soal objektif dan uraian. Pengumpulan data prestasi belajar siswa dilakukan pada setiap akhir masing-masing siklus. Data keterlaksanaan pembelajaran dikumpulkan dengan menggunakan metode observasi yang dilakukan selama kegiatan pembelajaran berlangsung pada setiap pertemuan. Sedangkan catatan lapangan dibuat oleh peneliti dan teman sejawat dengan melakukan pencataan tentang apa yang didengar, dilihat, dialami dan dipikirkan saat observasi dilakukan.

Data aktivitas belajar siswa dianalisis dengan menggunakan analisis statistik deskriptif, dan digolongkan berdasarkan kriteria dari Nurkancana dan Sunartana (1992:100). Data prestasi belajar siswa dianalisis secara statistik deskriptif yaitu dengan menentukan nilai rata-rata prestasi belajar siswa (M), Ketuntasan Belajar (KB) dan Daya Serap (DS).

\section{Hasil dan Pembahasan}

Data awal penelitian ini diketahui nilai rata-rata prestasi belajar yang diperoleh siswa adalah 39,5, daya serap 39,5\% dan ketuntasan belajar mencapai $20 \%$. Nilai yang diperoleh siswa tersebut belum memenuhi kriteria ketuntasan minimal yang telah ditetapkan yaitu, nilai rata - rata prestasi belajar siswa $\geq 65$, ketuntasan belajar $\geq 85 \%$, dan daya serap $\geq 65 \%$. Melihat hal tersebut, maka sangat perlu untuk diperbaiki aktivitas dan prestasi belajar matematika siswa kelas IV A SDK Warat dengan cara menerapkan model pembelajaran kooperatif tipe TPS.

Berdasarkan hasil analisis data aktivitas belajar siswa diperoleh rata-rata skor aktivitas siswa seperti pada tabel berikut.

Tabel 1. Hasil Analisis Data Aktivitas Belajar Siswa

\begin{tabular}{clcc}
\hline Siklus & Pertemuan Ke- & Rata-rata Aktivitas Belajar Siswa & Keterangan \\
\hline \multirow{4}{*}{ I } & 1 & 30,95 & Kurang aktif \\
& 2 & 44,4 & Cukup aktif \\
& Rata-rata & 37,67 & Cukup aktif \\
& 4 & 51,35 & Aktif \\
II & 5 & 56,3 & Aktif \\
& Rata-rata & 53,83 & Aktif \\
\hline
\end{tabular}

Selanjutnya, hasil analisis data prestasi belajar siswa dan keterlaksanaan pembelajaran dapat dilihat pada tabel 2 dan tabel 3 berikut.

Tabel 2. Hasil Analisis Data Prestasi Belajar Siswa

\begin{tabular}{llcc}
\hline \multicolumn{1}{c}{ Indikator Prestasi } & \multicolumn{2}{c}{ Hasil Analisis Data } & $\begin{array}{c}\text { Persentase Peningkatan dari } \\
\text { Siklus I ke Siklus II }\end{array}$ \\
\hline Rata-rata nilai prestasi & \multicolumn{1}{c}{ Siklus I } & Siklus II & $21,63 \%$ \\
belajar siswa (M) & 62,65 & 76,2 & $38,46 \%$ \\
Ketuntasan Belajar (KB) & $65 \%$ & $90 \%$ & $21,63 \%$ \\
Daya Serap (DS) & $62,65 \%$ & $76,2 \%$ & \\
\hline
\end{tabular}

Dari hasil analisis data di atas, diperoleh peningkatan prestasi belajar siswa dari siklus I ke siklus II prestasi belajar siswa sebesar $21,63 \%$, daya serap sebesar $21,63 \%$, dan ketuntasan belajar sebesar $38,46 \%$.

Tabel 3. Hasil Analisis Data Keterlaksanaan Pembelajaran

\begin{tabular}{ccccc}
\hline No & Siklus & Pertemuan & Keterlaksanaan Pembelajaran & Keterangan \\
\hline \multirow{2}{*}{1} & \multirow{2}{*}{ I } & 1 & $75 \%$ & Cukup Baik \\
& & 2 & $78,57 \%$ & Cukup Baik \\
& & Rata-rata & $76,78 \%$ & Cukup Bak \\
2 & II & 4 & $85,71 \%$ & Baik \\
& & 5 & $92,86 \%$ & Sangat Baik \\
\hline
\end{tabular}


Pada siklus 1 dilakukan 3 kali pertemuan dengan rincian dua kali pertemuan untuk pelaksanaan tindakan dan satu kali pertemuan untuk tes akhir siklus. Materi yang diajarkan dalam penelitian ini adalah pecahan, dengan rincian pertemuan pertama dan kedua membahas tentang bilangan pecahan dan bentuk pecahan. Berdasarkan hasil analisis data pada siklus I diperoleh rata-rata skor aktivitas belajar siswa sebesar 37,67 dengan kategori "cukup aktif", nilai rata-rata prestasi belajar siswa sebesar 62,65, ketuntasan belajar sebesar $62,65 \%$, dan daya serap sebesar $65 \%$. Dapat dilihat bahwa adanya peningkatan prestasi belajar matematika siswa pada siklus I. Keterlaksanaan pembelajaran kooperatif TPS pada siklus I diperoleh sebesar 76,78\% dengan kategori "cukup baik". Karena hasil pelaksanaan siklus I belum memenuhi kategori minimal, dengan demikian penelitian dilanjutkan ke siklus II.

Beberapa catatan sebagai hasil observasi pada siklus I yakni: guru nampak terburu-buru dalam menyampaikan materi, masih ada siswa yang tidak memperhatikan saat guru menyampaikan materi, siswa masih belum terbiasa dengan penerapan model pembelajaran kooperatif tipe TPS sehingga suasana kelas menjadi kurang kondusif, masih ada siswa yang kurang aktif dalam kelompok belajar, siswa yang memiliki kemampuan akademik di atas rata-rata cenderung mengerjakan soal LKS secara individual, serta siswa yang masih terpengaruh dengan situasi di luar kelas saat pembelajaran berlangsung.

Untuk menanggulangi kendala-kendala yang ditemui pada pelaksanaan siklus I tersebut, dilakukan diskusi dengan teman sejawat untuk mengupayakan perbaikan tindakan yang akan dilaksanakan pada siklus II agar kendala-kendala yang terjadi pada siklus I bisa dikurangi. Adapun perbaikan tersebut yaitu: (1) menyampaikan materi dengan jelas dan perlahan, (2) peneliti memberikan pertanyaan-pertanyaan secara lisan dan spontan kepada siswa yang tidak memeperhatikan saat guru menjelaskan materi agara memfokuskan perhatian siswa, (3) membimbing siswa yang kurang aktif dalam berdiskusi dan menanyakan permasalahan yang sedang dihadapi dalam melakukan diskusi, dan (4) meminta siswa yang tidak memeperatikan temannya mengulang kembali apa yang dipresentasikan oleh temannya.

Pada siklus II dilakukan 3 kali pertemuan dengan rincian dua kali pertemuan untuk pelaksanaan tindakan dan satu kali pertemuan untuk tes akhir siklus. Berdasarkan penyempurnaan yang telah dilakukan pada pelaksanaan tindakan siklus II diperoleh bahwa rata-rata skor aktivitas belajar siswa sebesar 53,83 dengan kategori "aktif". Nilai rata-rata prestasi belajar siswa sebesar 76,2; ketuntasan belajar sebesar $90 \%$; dan daya serap sebesar $76,2 \%$, serta keterlaksanaan pembelajaran mencapai $89,28 \%$ dengan kategori "baik". Dari kondisi ini, terlihat bahwa pelaksanaan tindakan pada siklus II terjadi peningkatan dari siklus I dan mencapai kriteria minimal yang telah ditetapkan. Secara umum, pada siklus II tidak ditemukan lagi kendala-kendala yang berarti dalam proses pembelajaran. Perbaikan tindakan pada siklus I yang kemudian dilaksanakan pada siklus II memberi dampak positif dalam proses pembelajaran pada siklus II.

Berdasarkan uraian diatas, diperoleh bahwa semua kriteria keberhasilan minimal yang telah ditetapkan terpenuhi. Aktivitas dan prestasi belajar siswa kelas IVA SDK Warat menunjukan terjadinya peningkatan dari siklus I sampai siklus II, maka penelitian tindakan kelas yang difokuskan untuk meningkatkan aktivitas dan prestasi belajar siswa dalam pembelajaran pecahan melalui penerapan model pembelajaran kooperatif tipe TPS pada siswa kelas IVA SDK Warat semester I tahun pelajaran 2019/2020 dapat dikategorikan berhasil. Hal ini dapat dilihat dari persentase peningkatan rata-rata nilai prestasi belajar siswa, ketuntasan belajar, dan daya serap dari siklus I ke siklus II berturut-turut adalah 21,63\%, $38,46 \%$ dan 21,63\%. Pembelajaran kooperatif TPS selalu memberikan kesempatan yang lebih banyak kepada siswa untuk berpikir, menjawab dan saling memabantu.

Hasil penelitian ini memperkuat penelitian terdahulu seperti penelitian yang dilakukan oleh (Aisyah Wiyono, Mustamin Anggo, 2018; Raditya et al., 2015), Penelitian yang dilakukan oleh (Yusmanidar, 2018) yang mengatakan model pembelajaraan kooperatif TPS dapat meningkatkan hasil belajar matematika siswa kelas IV SD Negeri 6 Bukit batu. (Dharma et al., 2019)) menunjukan bahwa penerapan model pembelajaran TPS dapat meningkatkan kemampuan komunikasi matematis dan percaya diri peseta didik. Penelitian yang dilakukan oleh Cahyani (2018) menunjukan bahwa adanya peningkatan nilai siswa pada kemampuan berbicara setelah diterapkan model pembelajaran think-pairshare.

\section{Simpulan dan Saran}

Berdasarkan hasil analisis data dan pembahasan, maka dapat disimpulkan sebagai berikut. 1) Melalui penerapan model pembelajaran kooperatif tipe TPS pada siswa kelas IV A semester I SDK Warat dapat meningkatan aktivitas belajar siswa, yaitu dari kategori "cukup aktif" pada siklus I meningkat menjadi "aktif" pada siklus II. 2) Melalui penerapan model pembelajaran kooperatif tipe TPS pada siswa 
kelas IV A semester I SDK Warat dapat meningkatan prestasi belajar matematika siswa, yang ditunjukkan dengan peningkatan rata-rata nilai prestasi belajar siswa, ketuntasan belajar, dan daya serap dari siklus I ke siklus II berturut-turut sebesar: 21,63\%, 38, $46 \%$ dan 21,63\%.

Berdasarkan simpulan di atas, maka saran yang dapat disampaikan sebagai berikut. 1) Kepada guru matematika disarankan agar menerapkan pembelajaran kooperatif tipe TPS sebagai salah satu alternatif dalam pemilihan model pembelajaran matematika. 2) Karena penelitian ini terbatas pada peningkatan aktivitas dan prestasi belajar siswa dalam pecahan pada siswa kelas IV A SDK Warat semester I tahun pelajaran 2019/2020, maka peneliti lain yang berminat melakukan penelitian sejenis agar mengadakan penelitian secara lebih mendalam dengan mengambil subjek penelitian dan pokok bahasan yang berbeda dalam upaya meningkatkan aktivitas dan prestasi belajar siswa.

\section{Daftar Rujukan}

Aisyah Wiyono, Mustamin Anggo, K. (2018). Pengaruh Kecerdasan Emosional Terhadap Hasil Belajar Matematika Siswa Kelas VIII MTs Negeri Kendari. 6(2), 113-126.

Dharma, I., Pujiastuti, E., \& Harianja, M. (2019). Penerapan Model Pembelajaran TPS (Think-Pair-Share) untuk Meningkatkan Kemampuan Komunikasi Matematis dan Percaya Diri Peserta Didik Kelas X MIPA 1 SMA Negeri 6 Semarang Pada Materi Sistem Persamaan Tiga Variabel Tahun Pelajaran 2018/2019. PRISMA, Prosiding Seminar Nasional Matematika, 2, 239-246.

Fathani, A. H. (2009). Matematika Hakikat \& Logika. Ar-Ruzz Media.

Handayani, R. D., \& Yanti, Y. (2017). Pengaruh Model Pembelajaran Kooperatif Tipe Think Pair Share Terhadap Hasil Belajar Pkn Siswa Di Kelas IV MI Terpadu Muhammadiyah Sukarame Bandar Lampung. Jurnal Pendidikan Dan Pembelajaran Dasar, 4(2), 107-123.

Hardyanti Arki, A. K., Auliah, A., \& Dini, I. (2017). Penerapan Metode Pembelajaran Kooperatif Tipe ThinkPair-Share Untuk Meningkatkan Hasil Belajar Siswa Kelas XI MIA.2 SMA Negeri 3 Model Takalar (Studi pada Materi Pokok Larutan Asam-Basa). Chemica: Jurnal Ilmiah Kimia Dan Pendidikan Kimia, 18(2), 71. https://doi.org/10.35580/chemica.v18i2.5899

Joyce B., Weil M., and C. E. (2009). No Title. Pustaka Pelajar.

Kurniasih, I. dan B. S. (2017). Ragam Pengembangan Model Pembelajaran. Kata Pena.

Leonard, Leonard, I. A. (2015). Pengaruh Metode Pembelajaran TPS ( Think Pair Share) Terhadap Hasil Belajar Matematika. Seminar Nasional Pendidikan Matematika Universitas Indraprasta PGRI, 26 Agustus 2015, Agustus, 139-145.

Majid, A. (2014). Strategi Pembelajaran. PT Remaja Rosdakarya.

Muhibbin Syah. (2008). Psikologi Pendidikan dengan Pendekatan Baru. PT Remaja Rosdakarya.

Muthoharoh, N. B. (2017). Pengaruh Model Pembelajaran Kooperatif "Think Pair Share” terhadap Hasil Belajar Bahasa Inggris. SAP (Susunan Artikel Pendidikan), 2(1), 33-42. https://doi.org/10.30998/sap.v2i1.1509

Notoatmodjo, S. (2003). Pendidikan dan Perilaku Kesehatan. PTRineka Cipta.

Raditya, I. W., Kristiantari, M. R., \& Suara, D. I. M. (2015). Pengaruh model pembelajaran kooperatif tipe think pair share (TPS) terhadap hasil belajar IPA siswa kelas VI SD Gugus Letda Made Putra Kecamatan Denpasar Utara tahun ajaran 2014/2015. E-Journal PGSD Universitas Pendidikan Ganesha, 3, 1-10.

Sanjaya, W. (2010). Strategi Pembelajaran Berorientasi Standar Proses Pendidikan. In 1. Prenada Media Group.

Susilo, H. dkk. (2008). Penelitian Tindakan Kelas sebagai Sarana Pengembangan Keprofesionalan Guru dan Calon Guru. Banyumedia Publishing.

Teresia Olivia Oennus, Erni, R. K. H. (2019). Pengaruh Penerapan Model Pembelajaran Example Non Example Terhadap Hasil Belajar Matematika. Oleh Teresia Olivia Oennus, Erni, Ramadhan Kurnia H. 1.

Trianto. (2009). Mendesain Model Pembelajaran Inovatif-Progresif. Kencana Prenada Media Group.

Trianto. (2011). Mendesain Model Pembelajaran Inovatif-Progresif. Prestasi Pustaka. 
Yusmanidar. (2018). Penerapan Model Pembelajaran Kooperatif Tipe Tps Untuk Meningkatkan Hasil Belajar Matematika Di Sd Negeri 6 Bukit Batu Kecamatan Bukit Batu. Yusmanidar SDN 6 Bukit Batu Kematan Bukit Batu Kabupataen Bengkalis PENDAHULUAN Matematika sering dianggap sebagai. Jurnal PAJAR (Pendidikan Dan Pengajaran) Program Studi Pendidikan Guru Sekolah Dasar FKIP Universitas Riau, 2(4), 563-571. 